\title{
Misinterpretation of patience: an analytical study of nerimo concept within Indonesian Muslim society
}

\author{
Adang Kuswaya \\ IAIN Salatiga, Indonesia \\ E-mail: dangkuswaya@gmail.com
}

\author{
Sukron Ma'mun \\ Western Sydney University, Australia \\ E-mail: s.mamun@westernsydney.edu.au \\ DOI: $10.18326 /$ ijims.v10i1.153-176
}

\begin{abstract}
This research aims to deeply explore the nerimo concept in Javanese Muslim society. Nerimo, as a philosophy of Javanese culture, is often associated with the concept of patience in Islamic doctrine. This research shows that there is a misconceived understanding and practice among the Javanese Muslim regarding the concept of nerimo and patience. They tend to explain nerimo and patience as a practice of passivity, static, and blind submission to all problems of life. This causes the values contained in those concepts to be reduced and lose the spirit of liberation for the life of mankind. By employing a liberation hermeneutics approach and sociological analysis, this research concludes that the nerimo concept in Javanese Muslim could indeed be reconstructed into a Javanese idea that implies human endurance in every period of life. The concepts of nerimo and patience are alternately a form of psychological, spiritual, and intellectual awareness of every life having a periodic motion, in which every person will certainly experience life fluctuations. Then the principle of patience and nerimo
\end{abstract}


become a catalyst for the position of life to turn it back into motion. Patience and nerimo, therefore, are not placed as results but are situated as the power of a continuity life process that is able to drive people to surpass one stage of their lives.

Penelitian ini bertujuan untuk mengeksplorasi konsep nerimo dalam masyarakat Muslim Jawa. Nerimo sebagai filosofi budaya Jawa sering dikaitkan dengan konsep kesabaran dalam doktrin Islam. Penelitian ini menunjukkan bahwa ada pemahaman dan praktik miskonsepsi di kalangan Muslim Jawa tentang konsep nerimo dan kesabaran. Mereka cenderung mengekspresikan nerimo dan kesabaran sebagai praktik kepasifan, statis, dan kepatuhan buta terhadap semua masalah kehidupan. Ini menyebabkan nilai-nilai yang terkandung dalam konsep-konsep tersebut menjadi berkurang dan kehilangan semangat pembebasan bagi kehidupan umat manusia. Dengan menggunakan pendekatan hermeneutika pembebasan dan analisis sosiologis, penelitian ini menyimpulkan bahwa konsep nerimo dalam Muslim Jawa sebenarnya dapat direkonstruksi menjadi gagasan Jawa yang menyiratkan ketahanan manusia dalam setiap periode kehidupan. Konsep nerimo dan kesabaran secara bergantian adalah bentuk kesadaran psikologis, spiritual, dan intelektual bahwa setiap kehidupan memiliki gerakan periodik di mana setiap orang pasti akan mengalami fluktuasi kehidupan. Maka prinsip kesabaran dan nerimo menjadi katalisator bagi posisi hidup untuk mengubahnya kembali menjadi gerak. Kesabaran dan nerimo, oleh karena itu, tidak ditempatkan sebagai hasil tetapi ditempatkan sebagai kekuatan dari proses kehidupan berkelanjutan yang mampu mendorong orang melampaui satu tahap kehidupan mereka.

Keywords: Patience; Nerimo; Javanese Muslim; Philosophy of Javanese culture

\section{Introduction}

Characteristics of Javanese people as polite, friendly, gentle, and respectful culture toward the others have been confirmed in various discussions. While Javanese people also embrace the character of resignation, surrender (mengalah) ${ }^{1}$

${ }^{1}$ There is a perspective in Javanese society that the phrase "surrender (mengalah)" derived from concept "meng-Allah (activity leads to God)" which is to break all material worldly desires and surrender all life only to God. So Javanese people often say "mengalah (surrender)" or 
and nerimo (acceptance) for everything in addressing various aspects of life. ${ }^{2}$ Cultural acculturation with Islamic faith is a gift in which Islam and Javanese culture do not conflict with each other but complement one another without losing their respective identities. ${ }^{3}$ This acculturation yielded the growth of philosophies of life wisely and prudently. ${ }^{4}$ Javanese culture is indeed rich in the noble philosophy of life and has become a guideline for achieving happiness in life, both derived from Javanese culture itself and the adoption of Islamic faith. ${ }^{5}$

The most obvious Islamic concept in this context is sabr (patience). Șabr ideally requires mankind to behave in a way that is acceptant of all forms of hindrances and trials given by Allah in the form of illness, disaster, poverty, and other instances of trials. ${ }^{6}$ The Quran mentioned the term $s$ $a b r$ in various places-in at least 103 verses with various derivatives of the word, spread in 46 Surah categorized into 29 Makkiyah and 17 Madaniyah. Term sabr comes from sabara, yashbiru, sabran, which has different meanings according to its context in various aspects and conditions, such as patience in worship, patience in trials and calamities, and so on. ${ }^{7}$

The Quran never used sabr in the form of passiveness and stagnation in dealing with something, while it is active and progressive in its defensive form of surviving trials from Allah. Ideally, sabr is a praiseworthy behavior refering to a positive value (virtue) of accepting all the wills of destiny. ${ }^{8}$

have a character who like to "surrender (mengalah)".

${ }^{2}$ Clifford Geertz, The Religion of Java, Chicago: University of Chicago Press, 1960, 13.

${ }^{3}$ Bambang Pranowo, Memahami Islam Jawa, Jakarta: Pustaka Alvabet, 2011, 32.

${ }^{4}$ Mark R Woodward, Java, Indonesia, and Islam. New York: Springer, 2011, 5.

${ }^{5}$ Ery Agus Kurnianto, "Refleksi Falsafah Ajaran Hidup Masyarakat Jawa dalam Prosa Lirik Pengakuan Pariyem Karya Linus Suryadi” Madah, Vol. 6, No. 1 (2015), 32.

${ }^{6}$ Hamka Hasan, "The Meaning of Patience in the al-Quran: Thematic Study of Verse al-Baqarah” Jurnal Bimas Islam, Vol. 6, No. 1 (2013), 229.

${ }^{7}$ Muhammad Fuad Abd Baqi, Mu'jam Al-Mufahras li Alfadh al-Qur'an al-Karim, Kairo: Dar al-Hadith, 1364 H, 507-509.

${ }^{8}$ Sarah A. Schnitker and Robert A. Emmons "Patience as a Virtue: Religious and Psychological Perspectives”, Research in the Social Scientific Study of Religion, Vol. 18. 
Notwithstanding, some Javanese Muslims sociologically still compare sabr with passive and static ways for dealing with problems. Sabr is often understood by the Javanese Muslim as a part of nerimo, which is one of the cultural values widely known and adopted by Javanese people nowadays. Nerimo attitude is a strong characteristic of individuals with Javanese cultural backgrounds. Nerimo is usually a passive attitude for dealing with disappointment and life difficulties while still being calm to prevent someone suffering from frustration and despair. Nerimo is a Javanese Muslim's manifestation of belief towards fate-a destiny that must be perceived. ${ }^{9}$

The majority of Javanese Muslims sociologically describe nerimo as a passive way and as giving the impression that someone must surrender and acquiesce to a situation without doing anything in dealing with a life problem. This conception then produces a character of weak-kneed mentality, lack of creativity, and one who easily gives up on achieving something, causing a shift in understanding of Javanese Muslims towards nerimo and sabr, shifting from active-progressive to passive-static. ${ }^{10}$ For example, the perspective of Javanese Muslims in understanding poverty is a destiny of God that cannot be denied. Some Javanese Muslims consider that they were deliberately born into the world by God in a poor state to give him a test of faith so that they must be responded with patience. This then led Javanese Muslims to work and practice "minimize" rather than "maximize". Some Javanese Muslims still believe no matter how hard they work and earn a living when God does not predestine them to be rich people, they will never be rich. This character subsequently makes some Javanese Muslims become passive and stagnant in innovating or doing their jobs.

Thus, this research intends to analyze the perspective of Javanese

\footnotetext{
${ }^{9}$ Pardi Suratno and Henniy Astiyanto, Gusti Ora Sare: 65 Mutiara Nilai Kearifan Budaya Jawa, Yoyakarta: Adiwacana, 2004, 151-152.

${ }^{10}$ Koentjaraningrat, Kebudayaan Jawa, Jakarta: Balai Pustaka, 1994.
} 
Muslims regarding nerimo concept, which is always identified with $\square a b r$. Not only does this research aim to disclose nerimo concept in Javanese Muslim tradition but will also discover the authentic meaning of patience in the Quran. It is expected, through this research, to reveal and explain the correlation between nerimo concept and patience in the Quran. This research will finally provide an alternative meaning to reconstruct a hierarchy of meanings of various possible derivations in the practice of the Javanese Muslim life contextually.

\section{Genealogy of nerimo philosophy}

Genealogically, nerimo philosophy could be traced from the cultural journey of the Javanese kingdom in the archipelago. The history of Javanese kingdoms could provide some clear clues regading the birth of nerimo culture in Javanese society. The existence of the kingdoms like Majapahit, Mataram, Demak, Singosari, Blambangan, the Jogjakarta Palace and Surakarta, etc., all of which carried the cultural formation of Javanese people including Muslims. ${ }^{11}$ For example, one culture of royal society, which has become a part of Javanese life, is a spirit of servitude as a servant of the king or ruler. Like the people who must serve the state, Javanese people always hold the principle to always submit to and obey the orders of the king. ${ }^{12}$ The kingdom always gave a doctrine that the kind people were those who could obey their king. Such compliance will usually bear prosperity, career progression, and protection from danger. So that inborn obedient character, submissive, acquiesce all forms of decisions and policies of the king, because reluctance will only get punishment, imprisonment, and death penalty. In this context, we can understand

${ }^{11}$ Purwadi, History of Java; Local Wisdom Description Since Ancient Mataram to Contemporary Era, Yogyakarta: Tanah Air, 2007. 2010 . 
that the culture of obedience (nerimo) is its own pride. This view is one of the factors why Javanese people have a tendency to always accept other people's treatment, although this can be a positive one as a form of respect and obedience to superiors. ${ }^{13}$

The next factor that shaped nerimo concept was the traces of colonialism in Indonesia, especially the land of Java. The long process of occupation in Java created a mentality of slaves and servants in Javanese identity. The forced labor system (rodi) or romusa had compelled Javanese people to submit to and follow all orders of the invaders. This practice, which has taken root for a couple of centuries, has crystallized in the character Javanese people. The process of internalizing the practices of daily life was then gradually taking root and multiplying in every person of Javanese society. ${ }^{14}$

Another psychological factor is that Javanese people have the character of "hesitancy or respect" to fellow Javanese people, especially with other tribes. Javanese people believe that wong urip iku ora biso urip dhewe (living cannot live alone), leading to the Javanese tendency to accept all forms of opinions, beliefs, and culture from outsiders. Perhaps this is what causes Javanese culture to be more accommodating of this form of diversity. In the Javanese perspective, in order to maintain harmony between people, someone must always respect the attributes of others to protect values (tata krama)..$^{15}$ The attitude of not being careful to refuse it can trigger conflict, showing high ethics deemed crucial to keep it up. Javanese people have a principle like wong Jowo nggone semu (Javanese people think it should not be always transparent), which indicates that Javanese people have pseudo

\footnotetext{
${ }^{13} Y$ Yeni Krismawati, "Falsafah 'Nrimo' dalam Budaya Jawa Ditinjau dari Tugas Pendidikan Kristen Berdasarkan Perspektif Psikologis”, Kurios, Vol. 1, No. 1 (2013), 24-25.

${ }^{14}$ Aman, Indonesia: dari Kolonialisme sampai Nasionalisme, Yogyakarta: Pujangga Press, 2014.

${ }^{15}$ Pardi Suratno and Henniy Astiyanto, Gusti Ora Sare: 65 Mutiara Nilai Kearifan Budaya Jawa, Yoyakarta: Adiwacana, 2004, 236.
} 
or symbolic social characteristics. That is, Javanese people are required to have subtle feelings in wicoro (speech) and solah bawa (behavior). Thus nerimo attitude becomes more of a choice to keep the relationship in harmony even though values are found to conflict both on the personal and societal levels. ${ }^{16}$

Nerimo character develops periodically through three systematic stages in the social structure of society. The first stage through the process of socialization is concerned with the process of learning culture in relation to the social system. This process usually occurs in children who get teaching nerimo culture both from school and through parents. The next stage is the enculturation process through habituation, inculcation of values, giving examples and daily practice. In this process, an individual learns and adjusts his/her thoughts and attitudes to customs, norm systems, and rules that exist in a culture. While the last stage is the process of internalizationas a long process since a person is born until he dies-in which he/she learns to instill in his/her personality all the feelings, desires, passions and emotions needed throughout his/her life. This process can be illustrated in a process of social interaction in a continuous community environment that makes it assimilated (affected) by the nerimo culture of the community, thus forming a nerimo character in a person. ${ }^{17}$ The environment plays a crucial role in the development of one's personality in giving birth to new cultural behavior that is distinctive with the culture of the community.

This process continues from generation to generation and develops into a shared personality building of Javanese society. Awareness of this internalization process is supported by the belief that everything that has become a Javanese cultural value must have noble values underlying the personality of a person and his/her community, including the will,

\footnotetext{
${ }^{16}$ Yeni Krismawati, "Falsafah "Nrimo" ..., 25.

${ }^{17}$ Yeni Krismawati, "Falsafah "Nrimo" ...., 26.
} 
ideals, ideas, and enthusiasm in achieving prosperity, safety, and happiness of inner and outer life. ${ }^{18}$ Nerimo attitude then becomes a fairly strong characteristic of individuals with Javanese cultural backgrounds to the present days.

\section{Concept of nerimo within Javanese Muslim society}

The philosophy of nerimo has been established very long in the psychology of Javanese society and has become entrenched in every aspect of Javanese life in general. According to Niels Mulder, nerimo is a form of accepting what is to everything by fostering peace of mind and emotional calm. Nerimo means knowing where to accept fate and thank God; this attitude creates satisfaction in fulfilling fate in the realization that everything has been outlined. ${ }^{19}$

Exploratively, nerimo character in the sociological review can be summarized in the following table:

Table 1. Variant Interpretation of Javanese Muslim towards Concept of Nerimo

\begin{tabular}{lllll}
\hline \multicolumn{1}{c}{ Subject } & Orientation & Attitude & \multicolumn{1}{c}{ Mentality } & Thought \\
\hline Wealthy Santri & Psychological & - & Pasive & Theology \\
$\begin{array}{l}\text { Impoverished } \\
\text { Santri }\end{array}$ & Spirituality & - & Determinism & Theology \\
$\begin{array}{l}\text { Pauper in } \\
\text { Rural }\end{array}$ & Spirituality & Serenity & Despairing & Theology \\
$\begin{array}{l}\text { Pauper in } \\
\text { Urban }\end{array}$ & Materialism & Restlessness & Pessimism & - \\
& & & &
\end{tabular}

\footnotetext{
${ }^{18}$ Koentjaraningrat, Kebudayaan, Mentalitas dan Pembangunan, Jakarta: Gramedi Pustaka Utama, 2002.

${ }^{19}$ Niels Mulder, Mysticism in Java: Ideology in Indonesia, Yogyakarta: Kanisius, 2005, 86.
} 


\begin{tabular}{ccccc}
\hline Subject & Orientation & Attitude & Mentality & Thought \\
\hline Rich Family & Materialism & Sufficiency & $\begin{array}{l}\text { Dread of } \\
\text { Destitute }\end{array}$ & - \\
\hline
\end{tabular}

Source: Authors

The table above briefly illustrates that the principle of nerimo departs from the realization that someone must follow destiny as it is impossible to escape from the line of his life's provisions. Nerimo is a belief that manungsa sakdrema nglakoni urip (humans only live life) and Gusti kang nentoake (God has the authority to determine). So, nerimo means believing in one's own destiny and being grateful to God because there is satisfaction in fulfilling what is part of it with awareness that everything has been determined. ${ }^{20}$

Essentially, the character of nerimo could yield different implications in reshaping someone's mentality caused by external factors where a person lives. For example, poor people living in a rural area will tend to be oriented in spiritual aspects. This means they can grasp that life must be fully accepted (nerimo) within the framework of devotion to God. Unlike poor people living in urban areas, not only will they feel uneasy because they have to experience social segregation, they are also more materially oriented because of their desire to be rich due to suffering from economic injustice. This difference is also depicted in the portrait of poor students (santri) who have a mentality of determinism, namely understanding that they were born into a world destined by God to be poor people, they fully believe that everything they experience has been designed by God. While the rich students (santri) will be more passive in their mentality due to their material sufficiency. Since they already have an established economy, wealthy students (santri) assume that they do not need to do anything

\footnotetext{
${ }^{20}$ Sugeng Pujileksono, Pengantar Antropologi: Memahami Realitas Sosial Budaya, Malang: Intrans Publishing, 2016, 110.
} 
(passive) and only surrender (nerimo) to the reality of life.

Niels Mulder explained that nerimo behavior is closely related to the world-view of the Javanese people, which is manifested in the form a unity of existence. According to Javanese Muslims, the unity of existence is essentially metaphysical and supra-rational. So it is perceived that human life is entirely an order that has been arranged and determined by a higher truth (God). This unity is subject to cosmic law (Sunnatullah), which is the law of certainty or the law of pinesthi-a law that states that humans, as God's creations, must take the line He has set. ${ }^{21}$

Ultimately, the concept of nerimo in Javanese Muslim tradition is intended as a form of adjustment to the overall order of the universe that has been arranged and coordinated so that it must be accepted. Thus, it is Javanese Muslims' moral duty to respect the orderly existence. Such an impulsive action or surrender to the will, lust, and indulgence in passion is despicable simply because those could degrade the personal, social, and cosmic order. So Javanese Muslims must be able to control themselves while building life beautifully.22

\section{Implications of nerimo character}

The cultural value system is an abstract conceptual series living in the mind of a society so that it affects a person's attitudes, behavior patterns, and lifestyle. The cultural value system becomes a source of moral ethics, which is described in the form of social norms, the legal system, manners, so as to determine how a person should think and behave in life.

By entrenching the nerimo concept in Javanese tradition, it has characterized a certain character formed due to the process of enculturalization, socialization, and internalization of the values contained

\footnotetext{
${ }^{21}$ Niels Mulder, Mysticism in Java: Ideology in Indonesia, Yogyakarta: Kanisius, 2005, 88.

${ }^{22}$ Suwardi Endraswara, Kebatinan Jawa; Laku Hidup Utama Meraih Derajat Sempurna, Yogyakarta: Lembu Jawa, 2011, 150.
} 
therein. Essentially, nerimo could have both negative and positive effects depending on how the education process goes on in a community as well as on people's perceptions of the concept. ${ }^{23}$ The misleading process of education and understanding of nerimo will lead the character to be passive, static, surrender to change without endeavor, and experience the powerlessness to deal with life problems. The critical education process, being more contextual and optimistic, can lead a person to possess a soul tough, calm, tolerant, not easy to complain, so one still has the spirit to potentially advance.

The fundamental problem of the concept of nerimo in Javanese tradition is that at a certain stage the character of nerimo can hamper someone's spirit of initiative and creativity. Nerimo philosophy tends not to provide space and possible opportunities to develop a reformer mentality by presenting fresh thoughts. Usually, someone with a nerimo character will tend to accept what they are without being critical and reconstructive about the situation. They only depend entirely on fate and walk blindly in dealing with problems that might be possible to be done. As a result, a person becomes more passive, does not dare to try something because he/she is afraid of what he/she will do as a mistake and tend to preferably wait for instructions as the best choice. ${ }^{24}$

The negative effect of nerimo characters is the death of productivity resulting in decreased work ethic. Someone becomes more lazy and tends to only rely on fate. They do not care how much they yield and evaluate continuously to improve their performance and results. This character displays a person who is easily satisfied with a small or even limited income. This fact then established the concept alon-alon waton

\footnotetext{
${ }^{23}$ Ridwan Saptoto, "Psychological Dynamics of Nerimo at Work: Nerimo as Motivator or Demotivator?”, Jurnal Psikologi Indonesia, Vol. 6, No. 2 (2009), 134.

${ }^{24}$ Noor Hanafi Prasetyo and M.A. Subandi, "Narimo Ing Pandum Intervention Program to Enhance Psychological Well-Being of Family Caregiver of Schizophrenic Patient", Jurnal Intervensi Psikologi, Vol. 6, No. 2 (2014).
} 
kelakon (even though it worked slowly as long as it was expected). They tend not to bother thinking about how to increase income and improve deficiencies; they instead prefer to relax and surrender to the situation. ${ }^{25}$ It generates a person becoming more passive and suffering from feelings of inferiority and subordination to the more dominant forces around them. If this feeling continues, it is not impossible that it will lead to a contradiction, namely emerging feelings of anxiety, and envy towards the progress achieved by others.

The nerimo philosophy also causes a person to avoid challenges and avoid competing against something being out of his/her ratio. This characteristic is coupled with the possibility to have a mentality that easily gives up, surrenders to the situation and be low-powered in struggle. ${ }^{26}$ In the end, someone with nerimo character will lose their courage to deal with challenges.

A person with a mentality built from nerimo philosophy is a figure that will easily escape from problems and is reluctant and frightened to take risks. The influence of this value at an acute stage will educate someone to be a person preferring to be controlled (subordinate) rather than a leader. ${ }^{27}$ They have a low level of confidence in their abilities and are afraid of giving direction to the others. This character also becomes riskier to experience turmoil or doubt in life due to his/her inability to respond to problems.

One weakness of nerimo philosophy is the loss of one's ability to bravely make decisions based on his/her own choice of opinion. Even someone with nerimo character tends to agree with the other opinions, even it is though logically wrong simply because they feel afraid to confront (debate)

\footnotetext{
${ }^{25}$ Sugeng Pujileksono, Pengantar Antropologi: Memahami Realitas Sosial Budaya, Malang: Intrans Publishing, 2016, 112.

${ }^{26}$ Clifford Geertz, The Interpretation of Cultures: Selected Essays, New York: Basic Books, 1973.

${ }^{27}$ Niels Mulder, Mysticism $\mathcal{E}$ Everyday Life in Contemporary Java: Cultural Persistence and Change, Minnesota: Singapore University Press, 1983.
} 
others. This causes someone to be more scared to keep the truth. Because of nerimo culture, the confrontation of ideas and actions is not perceived as an alternative-creative solution to generate problem solving, owing to preferably accepting all ideas of others even if incorrect. The effect of this attitude is the compromise of violations in order to maintain what is considered right by the community. ${ }^{28}$

Another form of negative impact of nerimo is its characteristic that requires accepting the treatment of others that are detrimental even in order to maintain social harmony. Usually, Javanese people will tend to reverentially choose silence if there is a debate of opinions. This value is supported by Javanese philosophy about the necessity of tepo seliro (tolerance). Thus, it allows Javanese people to sacrifice their personal interests in order to maintain the established social relations. This is intended as a form of social persuasion from the principle of nerimo maintaining opinion that Javanese people are good, even though they are treated arbitrarily. However, this value can be positive for the growth of the need to appreciate, trust, and pay attention for the sake of creating togetherness. But the forced nerimo character can influence one's character to be difficult being transparent both oneself and the assessment of others. This then caused Javanese people to often hide themselves behind Tata Krama (courtesy) so that it would be difficult to distinguish between sincerity and falsehood. This kind of ethics is very effective in deceiving others so that the real situation is not revealed by others, ${ }^{29}$ The sustainability of this character model will even lead someone to easily hold grudges. ${ }^{30}$

The positive value that can be developed from the philosophy of nerimo

${ }^{28}$ Ridwan Saptoto. "Psychological Dynamics of Nerimo at Work: Nerimo as Motivator or Demotivator?”, Jurnal Psikologi Indonesia, Vol. 6, No. 2 (2009), 135.

${ }^{29}$ Suwardi Endraswara, Revolusi Mental dalam Buadaya Jawa, Yoyakarta: Narasi, 2015, 230.

${ }^{30}$ Ery Agus Kurnianto, "Refleksi Falsafah Ajaran Hidup Masyarakat Jawa dalam Prosa Lirik Pengakuan Pariyem Karya Linus Suryadi” Madah, Vol. 6, No. 1 (2015), 34. 
is the ability to control oneself. Nerimo attitude is the main concept of nerimo ing pandum philosophy, which is a source of inner peace, self-control, and it is a form of gratitude. This value leads to a calm soul, not rashly responding to something, and accepting whatever happens in life so as to be able to bring tolerance. This ability will encourage someone to not easily get angry and be able to think clearly (calm) in addressing various problems of life. Positively, nerimo can develop one's social-cognitive value to eliminate attitudes of acute selfishness, developing a humble attitude, not giving up, respecting others, being obedient to parents and teachers, maintaining harmony and manners (tata krama). ${ }^{31}$

Koentjaraningrat argued that nerimo concept in Javanese tradition has a strong spiritual dimension against globalization and modernization that have silenced the character of wise and polite local cultures. ${ }^{32}$ The concept of nerimo ing pandum has a multidimensional aspect that can lead Javanese people to have an attitude of full acceptance of the past, present, and all possibilities that will occur in the future. This attitude will lead to a graceful character (legowo) and not easily get caught up in an attitude of despair when thinking about past bitter experiences and future uncertainty. ${ }^{33}$ This character makes a personal figure that can manage emotions (emotional questions) and misery of life (adversity question) and can reduce the risk of depression due to disappointment when getting something beyond one's expectations. ${ }^{34}$

Ideally, the nerimo philosophy has never taught apathy, passivity, and

\footnotetext{
${ }^{31}$ Nisa A'rafiyah Tri Wulandari. "Filosofi Jawa Nrimo Ditinjau dari Sila Ketuhanan Yang Maha Esa”, JIPPK, Vol. 2, No. 2 (2017), 136.

${ }^{32}$ Koentjaraningrat, Kebudayaan Jawa, Jakarta: Balai Pustaka, 1994.

${ }^{33}$ Prayekti. "Konseptualisme dan Validasi Instrumen Narimo Ing Pandum (Studi pada SMK Jetis Perguruan Tamansiswa Yogyakarta)", Jurnal Bisnis Teori dan Implementasi, Vol. 10, No. 1 (2019), 37.

${ }^{34}$ Rizki Maharani, "Penerapan Falsafah Narimo Ing Pandum dalam Pendekatan PersonCentered Untuk Mengatasi Depresi Remaja”, Prosiding SNBK (Seminar Nasional Bimbingan dan Konseling), Vol. 2, No. 1 (2018), 208.
} 
surrender to circumstances. Because the philosophy is nerimo ing pandum. It is a unity that cannot be separated from the philosophy of makaryo ing nyoto (working in real or earnest). ${ }^{35}$ However, Javanese people tend to understand partially and separately the two concepts of sesanti (advice). ${ }^{36}$ Therefore, the ideal concept of nerimo is a combination of horizontal aspects, which is reflected in the earnest effort in realizing something, and the vertical aspect by relying on all these efforts only on God. The nerimo tradition teaches people not to be arrogant and selfish in life and does not necessarily consider success as an absolute form of personal effort. ${ }^{37}$

\section{Quranic world-view of patience}

Etymologically, the word șabr comes from Arabic "ṣa-ba-ra" which means to hold (al-mani') and to prevent (al-hubs). ${ }^{38}$ Ibn Manzur explained that sabr indicates a strong defense process for something and is the culmination of that thing too. ${ }^{39}$ Meanwhile, Al-Raghib Al-Isfahani emphasized the meaning of patience by associating it with the forms of difficulties or trials of life. ${ }^{40}$ So patience is an ability to hold back, be steadfast in facing something difficult, severe and worrying, and endeavor from difficulties, obstacles, and like to be excluded and maintained from good and true things. ${ }^{41}$ Patience is a mentality of fighters who are firm (survive), consistent

\footnotetext{
${ }^{35}$ Nisa A'rafiyah Tri Wulandari. "Filosofi Jawa Nrimo Ditinjau dari Sila Ketuhanan Yang Maha Esa”, JIPPK, Vol. 2, No. 2 (2017), 134.

${ }^{36}$ Rizki Maharani, "Penerapan Falsafah Narimo Ing Pandum dalam Pendekatan PersonCentered Untuk Mengatasi Depresi Remaja”, Prosiding SNBK (Seminar Nasional Bimbingan dan Konseling), Vol. 2, No. 1 (2018), 208.

${ }^{37}$ Suwardi Endraswara, Kebatinan Jawa: Laku Hidup Utama Meraih Derajat Sempurna, Yogyakarta: Lembu Jawa, 2011, 156.

${ }^{38} \mathrm{Ibnu}$ Faris, Mu'jam Maqāyis al-Lughah, Juz III. Tahqiq, M. Harun, Beirut: Dār al-Fikr, 1979, 329.

${ }^{39}$ Ibnu Manzur, Lisān al-'Arab, Tahqiq, Muhammad Syadhali, Beirut: Dār al-Ma'ārif, 1119 H, 2391.

${ }^{40}$ Al-Raghib Al-Isfahani, Al-Mufradat fi Gharib al-Qur'ān, Beirut: Dār al-Ma'rifah, tth, 359.

${ }^{41}$ M. Quraish Shihab (ed.), Ensiklopedi Al-Qur'an: Kajian Kosakata dan Tafsirnya, Ciputat: Letera Hati, 2007, 349.
} 
(struggle), and progressive in maintaining a situation so as not to fall into despair. ${ }^{42}$ This attitude has implications for the psychological and spiritual soul of a person to remain dynamic and active in the rules that have been determined by God (Sunnatullah) in dealing with various kinds of problems, trials, difficulties, and challenges in life.

While in the semantic review, according to Toshihiko Izutsu, the concept of șabr (patience, determination) is a common practice that was commonly practiced in the Arabian Peninsula long before the emergence of Islam. The concept of sabr according to Izutsu is one of pre-Islamic moral ideas that had been Islamized and adapted to Islamic doctrine. ${ }^{43}$ This then confirms that Islam, since its inception, has adopted elements of the cultural locality of society.

Patience is categorized as the main virtue that is closely related to the concept of shaja'ah (courage). The geographical context of the desert has forced Arab communities to have a high attitude of patience and courage for the sake of their tribal existence. Patience is interpreted as the character of the gallantry and virility of the representative of the troops on the battlefield. ${ }^{44}$ Even the attitude of patience has a parallel role with physical strength. This means that it is impossible for a person or a tribe to survive in the desert region without being supported by an attitude of determination in facing every difficulty that might be encountered. ${ }^{45}$

Semantically the word sabr is negated with the word jaza', which means an attitude of being fragile and does not have the ability to survive

${ }^{42}$ M. Yusuf, Dona Kahfi Ibala and Moh. Toriqul Chaer, "Sabar dalam Perspektif Islam dan Barat", Al-Murabbi, Vol. 4, No. 2 (2018), 242-243.

${ }^{43}$ Toshihiko Izutsu, Ethico-Religious Concepts in the Qur'an, Quebec: McGill-Queen's University Press, 2002, 101-102.

${ }^{44}$ Toshihiko Izutsu, Ethico-Religious Concepts Concepts in the Qur'an, Quebec: McGill-Queen's University Press, 2002, 102

${ }^{45}$ Toshihiko Izutsu, Ethico-Religious Concepts..., 102. 
(sustainable) and deal with threat and disasters of life (QS. 14: 21). ${ }^{46}$ \abr in Quranic discourse, in the sense of endurance and forbearance, is a significantly important element and dimension of jihad fi sabilillah. According to Asma Afsaruddin, term sabr (sabaru) was usually coupled with the term jihad (jahadu) including various derivations from both of them (QS. 3:142; 16:110, 47:31). ${ }^{47}$ This suggests that șabr is power (strength) possessed by someone in confronting or fighting misery and suffering with perseverance in the midst of the difficulties of life. ${ }^{48}$ That is why in the Islamic tradition, sabr's attitude is transformed into one of the qualities of one's faith. The concept of patience has a semantic relationship with Islam and Iman manifested in the form of taqwa (obedience to God). Thus, patience accompanied by courage is reflected in the spirit of martyrdom that is the moral strength in the face of death or other torture for the sake of upholding the faith. ${ }^{49}$

Thus, patience is a special aspect of faith that functions as support as well as a shield in the face of unpleasant circumstances. Șabr function is in the dimension of life's difficulties, while gratitude occupies the dimension of life's pleasure. ${ }^{50}$ Therefore, the concept of patience appears to have no correlation with passivity and blind submissiveness; so it does not have the power and willingness to seek improvement. ${ }^{51}$ It is precisely patient to give spirit to mankind that all forms of disasters, trials and problems in life

\footnotetext{
${ }^{46}$ Ibnu Manzur, Lisān al-'Arab, Tahqiq, Muhammad Syadhali, Beirut: Dār al-Ma'ārif, 1119 H, 2392.

${ }^{47}$ Asma Afsaruddin, Striving in the Path of God: Jihad and Martyrdom in Islamic Thought, Oxford; Oxford University Press, 2013, 179.

${ }^{48}$ A.R. Mehdi Pour and N. Mongasthi, "Education of Patience in the Social Relations in the Qur'an" Walia Journal, Vol. 30, No. 1 (2014), 337.

${ }^{49}$ Toshihiko Izutsu, Ethico-Religious Concepts..., 103.

${ }^{50}$ Sarah A. Schnitker, "An Examination of Patience and Well-Being", The Journal of Positive Psychology, Vol. 7, No. 4 (2012), 278.

${ }^{51}$ Asma Afsaruddin, Striving in the Path of God, Jihad and Martyrdom in Islamic Thought, Oxford; Oxford University Press, 2013, 185.
} 
must be dealt with responsibly and wisely. So, in any context patience is understood both in terms of physical-material and non-physical-immaterial; it should be understood as a framework of worship to God..$^{52}$

\section{Reconstructing meaning of patience and nerimo}

First and foremost, nerimo should be expressed as the indigenization of self-acceptance construction in the Javanese Muslim tradition. It must not be understood as apathy, passivity and blind surrender but should be actively implemented as the principle of nerimo encouraging humans to be willing and able to work hard, while the results are entirely prerogative to God. Based on this perspective, nerimo is a form of teaching to always behave patiently and consistently to what is aspired to despite failure. This perspective will shape the character and behavior of men wisely and not in a greedy way. Human life is not only oriented toward a world of harsh competition, but toward a world formation promoting togetherness, collaboration, and peace in living life. ${ }^{53}$

Furthermore, this concept should subsequently be developed through a form of psychological, spiritual, and intellectual awareness that every life has a periodic motion where every person will surely experience life fluctuations. ${ }^{54}$ Then the principle of nerimo becomes a catalyst for the position of life to change it and move again. It means that nerimo is not perceived as being oriented toward accepting (results), but is perceived as a process of continuity of life being able to move people through one stage of their lives. This is an understanding of nerimo concept, which is more

\footnotetext{
${ }^{52}$ El-Sayed El-Aswad. "Patience in Sunni Muslim Worldviews" in David A. Leeming. Encyclopedia of Psychology and Religion. Boston: Springer Science and Business Media, 2014, 1320.

${ }^{53}$ Adinda Nurul Triaseptiana and Ika Herdiana. "Gambaran Kesehatan Mental Narapidana Bersuku Jawa Ditinjau dari Konsep Nrimo”, Jurnal Psikologi Kepribadian dan Sosial, Vol. 2, No. 1 (2013), 5.

${ }^{54}$ Noor Hanafi Prasetyo and M.A. Subandi, "Narimo Ing Pandum Intervention Program to Enhance Psychological Well-Being of Family Caregiver of Schizophrenic Patient", Jurnal Intervensi Psikologi, Vol. 6, No. 2 (2014).
} 
active, dynamic, and progressive for the Javanese Muslim.

Regarding sabr, patience is one of the fundamental characteristics of pious people who are always oriented toward changing for a better life. Patience is self-defense against the bitterness of life and showing the concept of patience is not oriented toward the process of total acceptance of a product of life blindly so that it is identified with incapacity and oppression..$^{55}$ Indeed, patience is a dimension of human consciousness to change a personal and social condition for the better. So patience is more active, dynamic, and progressive about the movement of human life. ${ }^{56}$ Thus, patience never has a connotation of passive, static, weakness, surrender; it is a struggle illustrating the power of the culprit to defeat (control) the desires of his/her lust for despair.

Figure 1:

\begin{tabular}{|c|c|c|c|c|}
\hline Subject & Orientation & Attitude & Mentality & Thought \\
\hline $\begin{array}{l}\text { Wealthy } \\
\text { Santri }\end{array}$ & Psychological & & Pasive & Theology \\
\hline $\begin{array}{l}\text { Impoverished } \\
\text { Santri }\end{array}$ & Spirituality & - & Determinism & Theology \\
\hline $\begin{array}{l}\text { Pauper in } \\
\text { Rural }\end{array}$ & Spirituality & Serenity & Despairing & Theology \\
\hline $\begin{array}{l}\text { Pauper in } \\
\text { Urban }\end{array}$ & Materialism & Restlessness & Pessimism & - \\
\hline Rich Family & Materialism & Sufficiency & $\begin{array}{l}\text { Dread of } \\
\text { Destitute }\end{array}$ & - \\
\hline
\end{tabular}

Source: Authors

\footnotetext{
${ }^{55}$ MK Ridwan and Adang Kuswaya, "Agama; Antara Cita dan Kritik", Fikrah, Vol. 4, No. 1 (2016).

${ }^{56}$ Sukino, "The Concept of Patient in al-Quran and Contextualize in Purpose Human Life Through Education” Ruhama, Vol. 1, No. 1 (2018), 76.
} 
Based on the above figure, it can be understood that although nerimo has a negative dimension, the concept of nerimo can be reconstructed in a more positive one. Nerimo is understood as an affective character that regulates a person remaining calm in accepting the factuality of life from the outside, which is bitterness, suffering, and disappointment. So, nerimo character is a combination of human rationality and emotional life. Nerimo is an active blend of cognitive and affective elements that can produce optimism and survival..$^{57}$

Borrowing Abdullah Saeed's term, nerimo must be interpreted contextually ${ }^{58}$ following the development of human intellectuality so that the personal character of nerimo remains relevant in dealing with globalization and neo-liberalism. Nerimo conceptions also need to be expressed as an element of liberation for the oppressed thinking of materialism and forms of world greed. ${ }^{59}$ From this perspective, Javanese people-with their nerimo character-are able to walk with a balance between being spiritual, emotional and intellectual in competing with the world community in order to realize the welfare of life.

Thus, nerimo-in Javanese Muslim society-must be developed into an expression of the possibility of changing structural conditions. Nerimo is located in a functional position to meet "unacceptable" situations. So nerimo serves more as a guide for human movement in organizing itself to see the positive things behind a difficulty (finding wisdom). Nerimo is developed as a positive energy renewal from the nature of discouragement

\footnotetext{
${ }^{57}$ Qurotul Uyun and Evelin Witruk, "The Effectiveness of Sabr (Patience) and Salat (Prayer) in Reducing Psychopathological Symptoms after the 2010 Merapi Eruption in the Region of Yogyakarta, Indonesia", Conference: The 5th International Congress on Interdisciplinary Behaviour and Social Science, 2017: 170.

${ }^{58}$ Abdullah Saeed, Interpreting the Quran: Toward a Contemporary Approach, New York: Routledge, 2006, 9.

${ }^{59}$ Farid Esack, Qur'an, Liberation, and Pluralism; An Islamic Perspective of Interreligious Solidarity againts Oppression, Oxford: Oneworld Publications, 1997, 30.
} 
and submission to the dimension of belief in the continuation of a period of life.

\section{Conclusion}

This article has attempted to explain the Quranic world-view (weltanschauung) of sabr. Sabr (patience) is an ability to hold and prevent things that can be suffered and detrimental to others. Humans must strive actively and dynamically to get out from difficulties, losses, trials in life. In essence, a person's ability to be patient must always be developed in daily life to avoid the growth of emotional attitudes, haste, despair and pessimism in addressing various problems of life. Patience can only be achieved by someone who has determination and courage in his/her soul to always improve themselves and analyze their deficiencies.

Nerimo is philosophically a noble and great way for providing more balanced life guidance. On the one hand, it is not trapped in egoism, arrogance, and materialistism, and on the other hand, it prevents someone from being anxious, pessimistic and weak in dealing with life's problems. Therefore, nerimo-being associated by $s a b r-i s$ a spirit implying human endurance in every period of life. This concept can be developed through a form of awareness, of which the nature is psychological, spiritual, and intellectual, which every life has a periodic motion, in which a person will experience life fluctuations. Then the principle of nerimo becomes a catalyst for life's position to change it to move again. This means that nerimo is not placed as a result oriented toward acceptance, but is placed as a process of life continuity that is able to move people through one stage of their lives. This is a more relevant, active, dynamic, and progressive understanding of the Javanese Muslims for dealing with globalization and onslaught of economic neo-liberalism in the 21st century.

\section{References}


Abd Baqi, Muhammad Fu'ad. Mu'jam Al-Mufahras li Al-Fadzi Al-Quran Al-Karim. Kairo: Darul Hadist, 1364 H.

Afsaruddin, Asma. Striving in the Path of God: Jihad and Martyrdom in Islamic Thought. Oxford; Oxford University Press, 2013.

Al-Isfahani, Al-Raghib. Al-Mufradat fi Gharib al-Qur'ān. Beirut: Dār al-Ma'rifah, n.a. Aman. Indonesia: dari Kolonialisme sampai Nasionalisme. Yogyakarta: Pujangga Press, 2014.

El-Aswad, El-Sayed, "Patience in Sunni Muslim Worldviews" in David A. Leeming. Encyclopedia of Psychology and Religion. Boston: Springer Science and Business Media, 2014: 1318-1321.

Endraswara, Suwardi. Kebatinan Jawa; Laku Hidup Utama Meraih Derajat Sempurna. Yogyakarta: Lembu Jawa, 2011.

Endraswara, Suwardi. Revolusi Mental dalam Budaya Jawa. Yoyakarta: Narasi, 2015. Esack, Farid. Quran, Liberation, and Pluralism; An Islamic Perspective of Interreligious Solidarity againts Oppression. Oxford: Oneworld Publications, 1997.

Faris, Ibnu. Mu'jam Maqāyis al-Lughah. Tahqiq, Muhammad Harun. Beirut: Dār al-Fikr, 1979.

Geertz, Clifford. The Interpretation of Cultures: Selected Essays. New York: Basic Books, 1973.

Geertz, Clifford. The Religion of Java. Chicago: University of Chicago Press, 1960. Hasan, Hamka, "The Meaning of Patience in the al-Quran: Thematic Study of Verse al-Baqarah”, Jurnal Bimas Islam, Vol. 6, No. 1 (2013): 213-233.

Izutsu, Toshihiko. Ethico-Religious Concepts in the Quran. Quebec: McGill-Queen's University Press, 2002.

Koentjaraningrat. Kebudayaan Jawa. Jakarta: Balai Pustaka, 1994.

Koentjaraningrat. Kebudayaan, Mentalitas dan Pembangunan. Jakarta: Gramedi Pustaka Utama, 2002.

Krismawati, Yeni, "Falsafah "Nrimo" dalam Budaya Jawa Ditinjau dari Tugas Pendidikan Kristen Berdasarkan Perspektif Psikologis”, Kurios, Vol. 1, No. 1 (2013): 22-34.

Kurnianto, Ery Agus, "Refleksi Falsafah Ajaran Hidup Masyarakat Jawa dalam Prosa Lirik Pengakuan Pariyem Karya Linus Suryadi”, Madah, Vol. 6, No. 1 (2015): 31-42.

Maharani, Rizki, "Penerapan Falsafah Narimo Ing Pandum dalam Pendekatan Person-Centered untuk Mengatasi Depresi Remaja", Prosiding SNBK (Seminar

Nasional Bimbingan dan Konseling), Vol. 2, No. 1 (2018): 205-212.

Manzur, Ibnu. Lisān al'Arab. Tahqiq, Muhammad Syadhali. Beirut: Dār alMa’ārif, $1119 \mathrm{H}$. 
Mulder, Niels. Mysticism $\mathcal{E}$ Everyday Life in Contemporary Java: Cultural Persistence and Change. Minnesota: Singapore University Press, 1983.

Mulder, Niels. Mysticism in Java: Ideology in Indonesia. Yogyakarta: Kanisius, 2005. Pour, A.R. Mehdi and Mongasthi, N. "Education of Patience in the Social Relations in the Quran”, Walia Journal, Vol. 30, No. 1 (2014): 335-338.

Pranowo, Bambang. Memahami Islam Jawa. Jakarta: Pustaka Alvabet, 2011.

Prasetyo, Noor Hanafi and Subandi, M.A. "Narimo Ing Pandum Intervention

Program to Enhance Psychological Well-Being of Family Caregiver of

Schizophrenic Patient”, Jurnal Intervensi Psikologi, Vol. 6, No. 2 (2014): 151-170.

Prayekti. "Konseptualisme dan Validasi Instrumen Narimo Ing Pandum (Studi pada SMK Jetis Perguruan Tamansiswa Yogyakarta)”, Jurnal Bisnis Teori dan Implementasi, Vol. 10, No. 1 (2019): 31-39.

Pujileksono, Sugeng. Pengantar Antropologi: Memahami Realitas Sosial Budaya.

Malang: Intrans Publishing, 2016.

Purwadi. History of Java; Local Wisdom Description Since Ancient Mataram to Contemporary Era. Yogyakarta: Tanah Air, 2007.

Raffles, Thomas Stamford. The History of Java. Cambridge: Cambridge University Press, 2010.

Ridwan, MK and Kuswaya, Adang. "Agama; Antara Cita dan Kritik", Fikrah, Vol. 4, No. 1 (2016): 154-170.

Saeed, Abdullah. Interpreting the Quran: Toward a Contemporary Approach. New York: Routledge, 2006.

Saptoto, Ridwan. "Psychological Dynamics of Nerimo at Work: Nerimo as Motivator or Demotivator?”, Jurnal Psikologi Indonesia, Vol. 6, No. 2 (2009): 131-137.

Schnitker, Sarah A. "An Examination of Patience and Well-Being", The Journal of Positive Psychology, Vol. 7, No. 4 (2012): 263-280.

Schnitker, Sarah A. and Emmons, Robert A. "Patience as a Virtue: Religious and Psychological Perspectives", Research in the Social Scientific Study of Religion, Vol. 18. (2007): 177-208.

Shihab, M. Quraish (ed.). Ensiklopedi Al-Quran: Kajian Kosakata dan Tafsirnya. Ciputat: Letera Hati, 2007.

Sukino, "The Concept of Patient in al-Quran and Contextualize in Purpose Human Life Through Education”, Ruhama, Vol. 1, No. 1 (2018): 63-77.

Suratno, Pardi and Astiyanto, Henniy. Gusti Ora Sare: 65 Mutiara Nilai Kearifan Budaya Jawa. Yoyakarta: Adiwacana, 2004. 
IJIMS: Indonesian Journal of Islam and Muslim Societies, Volume 10, Number 1, June 2020: 153-176

Triaseptiana, Adinda Nurul and Herdiana, Ika, "Gambaran Kesehatan Mental Narapidana Bersuku Jawa Ditinjau dari Konsep Nrimo", Jurnal Psikologi Kepribadian dan Sosial, Vol. 2, No. 1 (2013): 1-6.

Uyun, Qurotul and Witruk, Evelin. "The Effectiveness of Sabr (Patience) and Salat (Prayer) in Reducing Psychopathological Symptoms after the 2010 Merapi Eruption in the Region of Yogyakarta, Indonesia", Conference: The 5th International Congress on Interdisciplinary Behavior and Social Science, 2017: 165-173.

Woodward, Mark R. Java, Indonesia, and Islam. New York: Springer, 2011.

Wulandari, Nisa A'rafiyah Tri, "Filosofi Jawa Nrimo Ditinjau dari Sila Ketuhanan Yang Maha Esa”, JIPPK, Vol. 2, No. 2 (2017): 132-138.

Yusuf, M., and Ibala, Dona Kahfi, MA, and Chaer, Moh. Toriqul. "Sabar dalam Perspektif Islam dan Barat”, Al-Murabbi, Vol. 4, No. 2 (2018): 233-246. 